IRSH 52 (2007), pp. 445-475 DOI: I0.1017/S0020859007003069

(C) 2007 Internationaal Instituut voor Sociale Geschiedenis

\title{
The Rise of the Insecure Professionals
}

\author{
CHRIS NOTTINGHAM
}

Summary: The role of professions in the development of advanced industrial societies has long been recognized - for example, by Harold Perkin. However, the focus has been on the higher professions. Other professions have usually been dealt with as imperfect variants, with Etzioni, typically, referring to nurses, schoolteachers, and social workers as "semi-professions". However, by conceptualizing such professions as social formations in their own right, as ladders of social mobility, and in terms of their permanent social and professional insecurity, it is possible to create a different picture both of their internal dynamics and broader influence. Members of such groups fostered types of social and political activity that became a recognisable feature of developed societies. Moreover, an appreciation of the distinctive ideational and professional contribution of insecure professions can offer a perspective on a number of the major concerns of social historians. The argument is illustrated by reference to the development of such professions mainly in England and Scotland.

I saw her myself [...] call out a great hulking lad nearly as big as herself, and give him two strokes of the cane. His mother - a vast woman - waited for her as she came out and told her what would happen to her if she ever dared to lay her hands onto her Sam again. The children shouted after her as she went down the village street. She walked on with her head high as though she saw and heard nothing. She was about nineteen at the time, at the height of her glory. [Jessie Chambers as a student teacher in I906.]

John Worthen, D.H. Lawrence: The Early Years I885-I9I2 (Cambridge, I992), p. I 23 .

Here is, for example, the new type of elementary teacher - a figure practically unknown forty years ago - drawn in part from the tradesmen and ambitious artisan population, and now, lately, from its own homes. It is exhibiting a continuous rise of standard, keen ambitions, a respect for intellectual things which is often absent in the populations among which it resides. Its members are not only doing their own work efficiently, but are everywhere taking the lead in public and quasi-public activities [...]. They are taking up the position in the urban districts which for many generations was occupied by the country clergy in the rural districts; providing centres with other standards than those of monetary success.

C.F.G. Masterman, The Condition of England (London, I909), pp. 83-84. 
When G.K. Chesterton, the conservative controversialist, sought to encapsulate the social transformations of the later decades of nineteenthcentury Britain, he produced a lament for the demise of a solid, selfassured, middle class which had dominated the society of his childhood. In the middle of the century, he argued, this class had been content to pursue its allotted destiny but had later pulled itself apart. Half had conceived an ambition to get into "society" and begun to ape their social betters, while the others had begun to express their social aspirations through "societies"; "I mean", he added, "Vegetarian Societies and Socialist Colonies and things of that sort". "While his assumption about the solidity and contentment of his old middle class suggests the simplifications of nostalgia, his recognition of the development of a social stratum identifying itself around a set of socio-political beliefs deserves further consideration.

My concern here is with this "other" middle class. A good deal of attention has been devoted to the established professionals, such as lawyers and doctors. ${ }^{2}$ Far less concern has been shown for what I shall call the insecure professionals, individuals who worked in the emerging fields of education, health, and social welfare, sometimes conceptualized as the "socialized professions", who form the core of this other middle class. ${ }^{3}$ For "kings-and-bishops" historians such professionals have always been insignificant; for radical, "bottom-up", historians they were neither victims nor potential heroic actors. Feminist historians have shown interest but they have been concerned with gender issues rather than the character of the stratum as a whole. Moreover, much discussion in the past two decades has been constrained, after Foucault, by a distaste for the "social control" of which they are assumed to be agents. There are numerous, essentially sympathetic, accounts of individual professions but, as Celia Davis complained of nursing histories, they are structured by teleological assumptions of dark pasts and better futures. ${ }^{4}$

Although this "Whig" approach is of limited usefulness, it does capture the way the leaders of these professions have conceptualized their condition. The established professions have been adopted as the ideal and "professionalizing" strategies adopted. But while conditions improved

I. G.K. Chesterton, Autobiography (London, I937), p. I6.

2. Most notably in the work of Harold Perkin. See Harold Perkin, The Rise of Professional Society: England since I 880 (London, 1989), and idem, The Third Revolution: Professional Elites in the Modern World (London, 1996).

3. See for instance the early study of British professions, A. Carr Saunders and P.A. Wilson, The Professions: Their Organisation and Place in Society (Oxford, I928), p. 5. Carr Saunders and Wilson recognized a category of "socialized" professions in which "the State employs technicians to give a direct service to the individual members of the public".

4. Celia Davies, "Introduction", in idem Davies (ed.), Re-Writing Nursing History (London [etc.], 1980). 
greatly during the course of the twentieth century the division between the insecure and the established remains a source of complaint.' Florence Nightingale's ambition for the nursing profession remains unfulfilled, and British school teachers, who developed their identity in the nineteenth century around opposition to muscular management from outside and "payment by results", were still involved in battles over an imposed national curriculum and performance targets at the end of the next century. ${ }^{6}$ This perpetual sense of legitimate aspiration denied produces key features, not least the susceptibility to the broad progressive enthusiasms identified by Chesterton. Ideology is most compelling when it promises to bridge a gap between aspiration and reality.

The last decades of the nineteenth century were a period when both the reality and the perception of middle-class existence were subject to complex change. Insistent voices proclaimed the "New". Enthusiasm for innovation stretched to sexual conduct, diet, clothing and domestic decor. Liberty prints became the mark of those who rode the new progressive wave. ${ }^{7}$ Gaunt detected a new urban hedonism: "men and women lived the life of the town". ${ }^{8}$ A recent study makes the link with a middle-class identity crisis: "If urban modernity was predicated on flux and transience how were social identities to be maintained?". Gunn suggests, as had Simmel and Toennies, that status under urban modernity was upheld by display, and stresses the importance of "the new social and physical spaces" for such purposes: "the city centre in particular was a principal site in which class identity was tested".?

If the capacity of many of the new professionals to participate was limited, their occupations usually provided a bit of geographical mobility and an interval between leaving home and establishing their own families. Even at the worst moments in the teaching profession politicians conceded that salaries should not fall beneath those of clerks and that women teachers should be able to live "respectably and singly". ${ }^{\circ}$ Teacher-training

5. See, for example, Christopher Hart, Nurses and Politics: The Impact of Power and Practice (Basingstoke, 2004).

6. See for example Alex Moore, "Compliance, Resistance and Pragmatism: The (Re)Construction of School Teacher Identities in Periods of Intensive Educational Reform", British Education Research Journal, 28 (2002), pp. 551-556.

7. The home of Grant Allen's "new woman" heroine in The Woman Who Did "was as dainty as Morris wallpapers, merino hangings, and a delicate female taste in form and colour could make it. Keats and Shelley lined the shelves; Rossetti's wan maidens gazed unearthly from the overmantel"; Grant Allen, The Woman Who Did (London, i895), p. 77.

8. William Gaunt, The Aesthetic Adventure (London, 1988) p. 83.

9. Simon Gunn, "The Public Sphere, Modernity and Consumption: New Perspectives on the History of the English Middle Class", in Alan Kidd and David Nicholls (eds), Gender, Civic Culture and Consumerism: Middle Class Identity in Britain I800-1940 (Manchester, 1999), pp. I $2-29$, I7 - I 8 .

I0. Committee of Council of Education Report, I859-1860, quoted in Donna F. Thompson, Professional Solidarity among the Teachers of England (New York, 1927), pp. 67-68. 


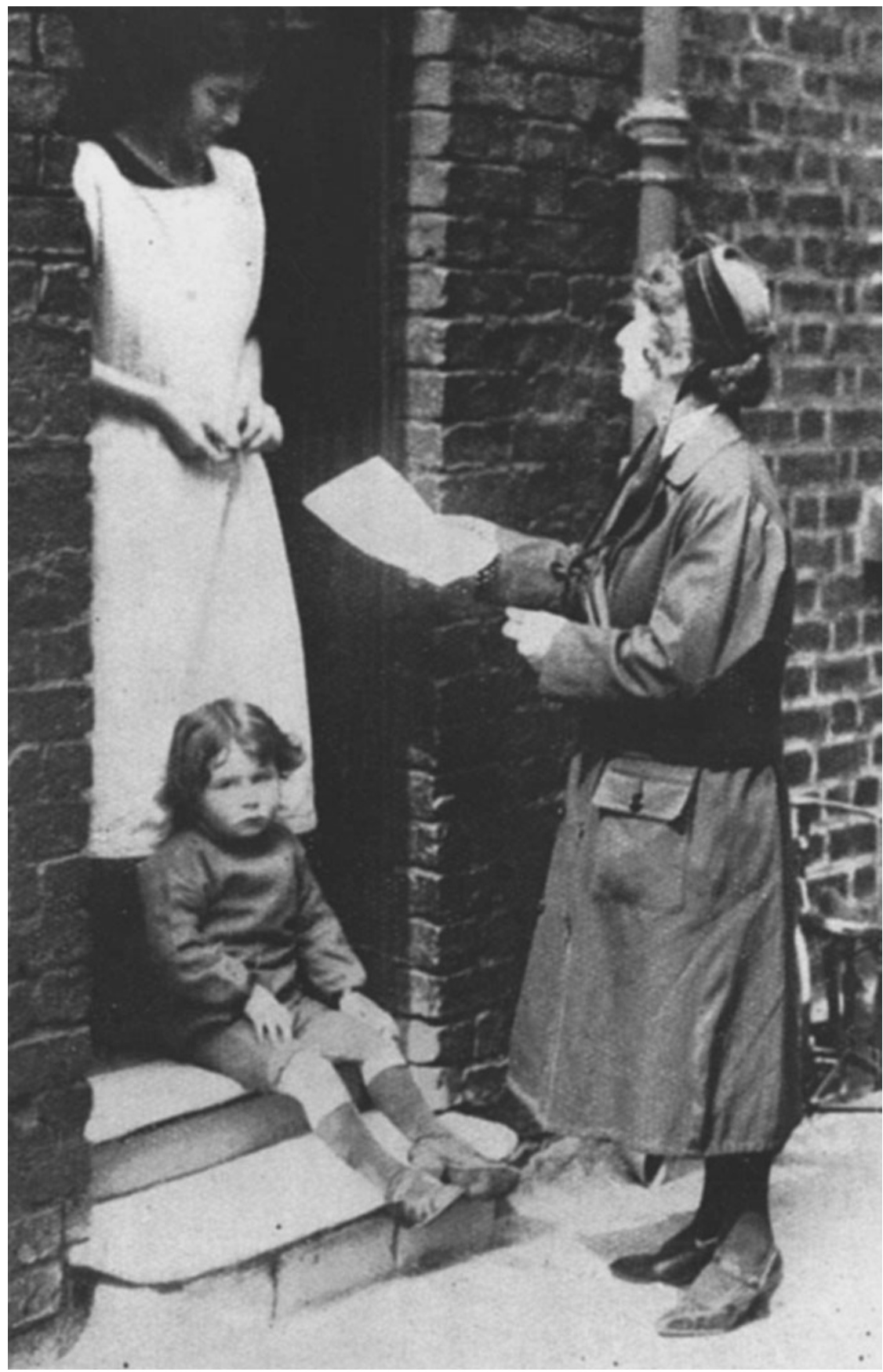

Figure I. Visitor to the Manchester City Mission, probably in the I920s.

Heatherbank Museum of Social Work, Glasgow Caledonian University. Used with permission. 
colleges and nurses' homes were scarcely hotbeds of hedonism but they provided some opportunity for "friendship, debating and dramatic societies, sports and visits to local theatres". ${ }^{\text {II }}$ Even local teachers' centres could provide an opportunity for students to develop beyond the family and immediate locality. ${ }^{\mathrm{I}}$ Subsequent life in the furnished room had its restrictions, but as Jonathan Raban argued, it was a vital foundation stone of the emerging "soft city". ${ }^{13}$

In the larger cities there were other opportunities. Radical societies, for example, provided the opportunity to discuss the new ways of living and thinking. This connects with one of the period's more remarkable features, the flowering of a new sort of intellectual; popular public figures with a wide readership. In these two decades Bernard Shaw, H.G. Wells, Sidney and Beatrice Webb, Havelock Ellis, and Edward Carpenter established themselves as progressive intellectual mentors. Edith Ellis joined the small army of freelance lecturers, and toured the provinces to spread her new "design for living" to "villa-bound, strenuous, and perplexed seekers after truth". ${ }^{14}$ Edwin Muir joined the Clarion Scouts in Glasgow and attended lectures on everything from free love, clothing reform, and vegetarianism to land nationalization. ${ }^{\text {Is }}$ A.R. Orage (at this time still an elementary school teacher) and Holbrook Jackson grew tired of outdoor meetings and founded an Arts Club in Leeds with a similar programme. Clearly the rise of such figures, of the magazines, of the provincial societies, and ventures such as Ernest Rhys's Everyman Press, rested on the existence of an audience thirsting for a new kind of intellectual stimulation. For Ellis, his mission was to: "the doctor in his consulting room, the teacher in the school, the preacher in the pulpit, the journalist in the press". ${ }^{16}$

There can, of course, be no perfect match between social beliefs and social formations. The progressive outlook certainly appealed to disaffected members of the established middle classes and found workingclass adherents, but I suggest that the main reservoir of support was a developing stratum: middle-class in certain respects but not all; men and women whose lives rested on the rapid expansion of education, social welfare, and health services. ${ }^{17}$ Their status, like much else in their lives, was

I. Frances Widdowson, Going up into the Next Class: Women and Elementary Teacher Training $1840-1914$ (London, 1983), p. 56.

I 2. See John Worthen's comment on the Teachers' Centre in Ilkeston for an insight into how an apparently unpromising milieu could encourage fledgling intellectual activities; John Worthen, D.H. Lawrence: The Early Years I885-19I2, (Cambridge, I992), pp. I I5-I I6.

I3. Jonathan Raban, Soft City (London, 1975).

I4. Mrs Havelock Ellis, Three Modern Seers (New York, I9I0), p. 47.

I 5. Edwin Muir, Autobiography, (London, 1987), pp. iाi-iा3. The "intellectuals", the selfdefined elite section of the Clarion Scouts, "was made up of school-teachers, civil servants, clerks, shop assistants, commercial travellers, masons, engineers, typists, nurses”, p. I24.

16. Havelock Ellis, The New Spirit (London, I890), p. I 5 .

17. See, for numerous examples of the impact of progressive literature on working and lower 
intermediate, tentative, and subject to challenge. Most lacked both the financial and social ease which the established professionals began to display by the end of the century. ${ }^{18}$ Many were drawn from working-class families for these professions were, for many, ladders of social mobility. ${ }^{19}$ This suggests, and personal accounts confirm, that the experience of class relations was often uncomfortable. The new status was fragile and abstract, resting on pieces of paper, certificates of matriculation, records of training, testimonials to worthiness. Material superiority was marginal, resting less on income than security of employment and superannuation. They had no easy command of styles of dress or habits of speech by which others commanded respect, yet their occupations demanded authoritative social performance in an age when it was necessary to "make power visible by the act of stylised public appearance". ${ }^{20}$

The introductory quotation dealing with Jessie Chambers's trials as an elementary school teacher catches the dilemma. Where the relationship between an established professional and a client involved choice on the part of the latter, the insecure professional was usually imposed on the client. Even worse, the insecure were often trapped between their clients and their regulators; the ward sister preparing patients for the consultant's rounds, the teacher drilling her pupils for the school inspector's scrutiny. They might regard themselves as agents of enlightenment, yet their clients might see them as missionaries of an alien culture and their superiors suspect them of succumbing to client pressure for the sake of an easy life. The Newcastle Commission of the mid-nineteenth century demanded that teachers be subjected to "a constant and stringent motive to induce them to do that part of their duty which is at once the most unpleasant and the most important". ${ }^{21}$ Working lives were located where pressures from above met resistance from below. They were in many

middle-class readers, Jonathon Rose, The Intellectual Life of the British Working Classes (New Haven, CT, 2002).

I8. See W.J. Reader, Professional Men: The Rise of the Professional Classes in Nineteenth Century England (London, 1966). Reader argued that by the last quarter of the nineteenth century the higher professions had lost any radical edge: "It was only natural, since they had achieved so much of what they had been campaigning for", p. I46.

19. The Department of Education recorded the social-class origins of those who obtained bursaries for teacher training in England and Wales in the years I909-I910. Less than 5 per cent were from families of the professional class, with around 46 per cent from white-collar groups (teachers, clerks, commercial travellers, minor officials), 38 per cent from manual workers' families (postmen, artisans, labourers etc.). Entrants from the manual working class were lower at this point than they had been in the second half of the nineteenth century when middle-class aspirants had found it difficult to compete with working-class entrants. See Peter Sandiford, The Training of Teachers in England and Wales (New York, I910), and Widdowson, Going up into the Next Class, pp. I $2 \mathrm{ff}$.

20. Gunn, "The Public Sphere, Modernity and Consumption", p. I9.

21. Report of the Royal Commission on Education i 858, quoted in Thompson, Professional Solidarity among the Teachers of England, p. 47. 
instances the administrators of unwelcome obligations; destined to deliver contentious decisions but with too little authority to do it comfortably. In theory the work of teaching or care suggested an opportunity for purposeful self-expression but in practice it could be an iron cage of regulation. The progressive agenda suggested an imagined world where the creative potential within these professions could be released and dignity bestowed on difficult working lives. It promised a world where teachers could become educators, nurses and social welfare workers make a positive contribution to the well-being of their clients, and all could unite in the task of social reconstruction within a rationally ordered welfare state.

The expansion of such professions around the turn of the nineteenth and twentieth centuries suggests a rise to critical mass. Between I88 I and I90I, according to one calculation, the number of teachers in Britain rose from I 23,000 to I72,000, and nurses from 38,000 to 68,000. ${ }^{22}$ Another suggests that the teaching profession in England and Wales expanded from a base of I 4,400 in I 870 , to 44,600 in I 880 , I I 9,000 in I 900 and I 64,000 in I 910 . The numbers for Scotland rose from 2,400 in 1870 to 20,000 in I910.. ${ }^{23} \mathrm{~A}$ general measure suggests male employment within "professional occupations and their subordinate services" rose from 254 ,000 in I 88 I, to 44 I, 000 in I92 I, with female employment more than doubling. ${ }^{24}$ By this last year the "lower professions" had become a census category and numbered 680,000 , or around 3.5 per cent of the total population. Of these, slightly under 60 per cent were female and slightly over 60 per cent worked in teaching, health, or social welfare. ${ }^{25}$

There was a similar growth in ambition. In nursing these years witnessed the birth of the modern profession. As early as I 872 the National Union of Elementary Teachers' journal urged teachers towards a "sense of their power". ${ }^{26}$ In I 886 the Union had I 2,000 members but by I 896 this had risen to 36,793 and the Union was sponsoring parliamentary candidates. ${ }^{27}$

22. See D.C. Marsh, The Changing Social Structure of England and Wales, I87I-I96I (London, 1977). Abel Smith records the number of nurses in England and Wales in I90I as 63,500, of whom 25,000 were trained "in the broadest sense"; Brian Abel Smith, A History of the Nursing Profession (London, I96I), p. 58.

23. B.R.Mitchell, European Historical Statistics 1750-1975 (London, I980), and see also Lee Holcombe, Victorian Ladies at Work: Middle Class Working Women in England and Wales I850-1914 (Newton Abbott, 1973).

24. Department of Employment and Productivity, British Labour Statistics, Historical Abstract I886-1968 (London, I97I), Table I02. "Professional occupations and their subordinate services" is an awkward category as it included entertainers and sportsmen but not vets or "druggists".

25. Guy Routh, Occupation and Pay in Great Britain 1906-1960 (Cambridge, 1965).

26. Ibid., pp. 85-86, quoting The Schoolmaster, i7 February I 872.

27. School Board Chronicle, 25 (1886). For the 1896 figure, see Sidney and Beatrice Webb, Industrial Democracy (London, I901), note on p. 826. 
By the time of World War I the Union had 100,000 members, around half of the profession. ${ }^{28}$

The growth in numbers and confidence were influenced by, and contributed to, that broad debate about a "social question" demanding more than random charity. State expansion set up the case for more activity. Compulsion in education produced the new profession of the school attendance officer, increased expenditure demanded a more efficient inspectorate, and knowledge of the physical condition of the poorest children pointed up the need for welfare officers. ${ }^{29}$ Something was stirring, even within poor law administration. In a report to the annual meeting of the Association of Poorhouse Governors of Scotland in I89I, William Dalgleish, Governor of the City Poorhouse, Aberdeen, argued that the "promotion of proper discipline" in poorhouse children required qualified teachers and superintendents. Similarly, the care of the sick poor had been "revolutionised so to speak" and was now in the hands of trained nurses. ${ }^{30}$ In England and Wales, under the Nursing in Workhouses Order of I 897 paupers could no longer be used for nursing duties; nurses must have had practical experience, and their supervisors three years' training in a nursing school. ${ }^{3}$ An English guardian argued that even the traditional task of identifying the "undeserving" required more and better qualified relieving officers. ${ }^{32}$

\section{SILENT AMBITION, LIMITED INCOME}

The attempt to establish the insecure professions as a category clearly runs across many strands of existing social history. I shall first attempt to locate it within discussions of middle-class development, and secondly set it in the context of at least some of the vast literature on professions. The lower middle classes have always been a problem for social historians. The relative neglect was noted by Crossick thirty years ago and in spite of notable additions the problem remains. Crossick suggested one difficulty was a "lack of heroism"; their unwillingness to assume "a role on the historical stage". ${ }^{33}$ Any unity was of the negative sort; they were unified only on not being working class.

28. Annual Report of the National Union of Teachers, I922, quoted in Thompson, Professional Solidarity among the Teachers of England, p. i 17.

29. Compulsory school attendance was introduced in England and Wales in I870 and in Scotland in 1872 .

30. Dalgleish was also anxious to stress improvements in the whole poor-law hospital sector: "Some of them are not equalled by the best equipped infirmaries in the country"; William Dalgleish, "Changes in Poor House Management", Poor Law Magazine, ns, I (I89I), p. 395.

31. Holcombe, Victorian Ladies at Work, pp. 86-87.

32. "Report of the Meeting of the Charity Organisation Society", Poor Law Magazine, ns, I (I89I), p. 4I2.

33. Geoffrey Crossick (ed.), The Lower Middle Class in Britain (London, 1974), p. I I. 
McKibbin has shown that this negative could, with cultivation, amount to a formidable positive for the Conservative Party. ${ }^{34}$ The "rate-payer" consciousness which Baldwin evoked in opposition to state expansion, inflationary economic policy, and militant trade-union action in the I920s re-established the Conservatives as the leading middle-class party, but this representation of middle-class identity was unlikely to arouse the enthusiasm of insecure professionals. Material interest was one obvious difficulty but there were others. Zeldin's comment that the lower middle classes must be studied through "largely silent ambitions, which take one out of the realm of economics or politics" is of relevance, for the silent ambitions of insecure professionals ran against this middle-class mainstream even more than their material interests. ${ }^{35}$ McKibbin suggests that the morale of the British middle classes hit its lowest moments in the early I 920 and last half of the $19405 .{ }^{36}$ Lewis and Maude began their 1950 study admitting they had considered "decline and fall of the middle classes" as a title. ${ }^{37}$

Yet for the insecure professionals, neither of these periods could possibly be seen as a moment of crisis. An active social state promised ideological satisfaction and material security. State-guaranteed pensions offered protection against anxieties produced by inflation. In the short burst of corporatism around the end of World War I a Ministry of Health was established, nurses secured their General Nursing Council, and many state employed professionals, through Whitley Councils, achieved the national pay scales for which they had long campaigned. Governments of the I940s introduced social reforms which professional leaders had long demanded and besides, the Labour Prime Minister's own political journey had begun with social work in the East End of London.

Their salaries set insecure professions within the middle class but in most cases, only marginally so. The NUT estimated that in I890 at least half of their membership, more than half of these promoted principal teachers, earned less than $\mathfrak{E}_{100}$ a year. ${ }^{38}$ The fact that Maude Pember Reeves called her book on the pinched lives of the poorest Londoners in work in the first decade of the twentieth century Round About a Pound a Week gives meaning to this figure. ${ }^{39}$ Under the Glasgow School Board in the I 880 os a qualified assistant teacher could expect between $£_{52}$ and $£_{90}$ per annum, with an average of $£ 8 \mathrm{I} .4^{\circ}$ In rural Lincolnshire the average pay

34. Ross McKibbin, Ideologies of Class, Social Relations in Britain I880-1950 (Oxford, 1990), particularly the chapter "Class and the Conventional Wisdom", pp. 259-302.

35. Zeldin, quoted in Crossick, The Lower Middle Class, p. 53.

36. Ross McKibbin, Classes and Cultures: England 19I8-195I (Oxford, 1998), p. 66.

37. Roy Lewis and Angus Maude, The English Middle Classes (London, I950).

38. Report on the Annual Conference of the National Union of Teachers as reported in School Board Chronicle, I53 (I 2 April I 890), p. 370.

39. Maude Pember Reeves, Round About a Pound a Week (London, 1913).

40. James M. Roxburgh, The School Board of Glasgow I873-1919 (London, I97I), pp. 34, 3I. 
of a male assistant was $£ 65$ but for females it was $£_{45} \cdot{ }^{4 I}$ The gender differential was universal and was compounded by women's exclusion from many higher positions. ${ }^{42}$ Many supplemented their incomes by taking responsibility for pupil teachers. ${ }^{43}$ Basic earnings were not directly dependent on a favourable inspector's report but without this, and support from the headteacher, teachers could neither apply for increases nor get another job. 44

Nurses' wages in the same period were lower. In London workhouses they got $£_{17}$ a year for a seventy-hour week with two weeks paid holiday and in a voluntary hospital they might expect $£_{2} 6$ for twelve hours a day, seven days a week. Food and accommodation were provided as payments in kind. Brian Abel Smith calculated that the average gross pay of nurses was $£ 57$ a year compared with the $£ 80$ that a female certificated teacher in London might expect. In I 889 the West London School District offered a schoolmistress $£_{3}$ o per annum "or such additional sum as may be awarded under certificate, together with rations and apartments and $£_{3}$ per annum in lieu of beer". ${ }^{45}$ Domiciliary nurses might expect between $£_{30}$ and $£_{50}$ with all found. They were regarded as an elite, partly because of their pay, but possibly also because, unlike nurses in hospitals, they dealt with mainly middle-class patients. The Glasgow Sick Poor and Private Nursing Association, as its name suggests, provided trained nurses both for "the sick poor" and "sick persons who are able to pay for their care." They demanded high standards of training: a minimum hospital training of three years. In 1906 they employed forty-nine qualified nurses with thirteen probationers. Nurses lived in the Association's home. An indication of their status is suggested by the record that a benefactress donated "a barrel of apples for the nurses". ${ }^{46}$

Details sometimes offer a better insight into the condition than raw salaries - for instance the advertisement that appeared in teachers' journals in the 1890 , "How to purchase a house for 2 guineas per month with immediate possession and no rent to pay", 47 or the fact that the Glasgow School Board in the 1890 s objected to the teachers' private trade in jotters

\footnotetext{
41. School Board Chronicle, is3 (5 April i890), p. 345.

42. In addition almost all "uncertificated" or "supplementary" teachers were women. In I 897 , for instance, of 35,627 "uncertificated" teachers in England and Wales, only 2,29I were men; NUT annual report quoting Thompson, Professional Solidarity among the Teachers of England, p. 104 .

43. Roxburgh, The School Board of Glasgow, p. 34.

44. Ibid., p. 40.

45. School Board Chronicle, I I ( 30 March I 889), p. 327. Abel Smith's estimate in Abel Smith, $A$ History of the Nursing Profession, p. 55.

46. Glasgow City Archives, Mitchell Library, Glasgow, Charity Organisation Society, T-PAR I-6.

47. School Board Chronicle, I5 I (30 March I889), p. 327.
} 
(exercise books) ${ }^{4}$ Salaries were pitched at a level which might initially excite hopes before slowly disappointing them. Maintaining the semblance of a middle-class life would require constant effort, living alone, or rigorous family limitation. As A.R. Orage, later to edit the New Age, a house journal of the progressive tendency, discovered, his annual salary of $\mathfrak{8 0}$ as an elementary school teacher in Leeds was adequate for one but left two in relative penury.49 Yet, for many entrants these professions represented a broadening of experience, an improvement in status, and greater long-term material security. In terms of income they were just about middle-class, yet other factors, in particular the ideational and material implications of their position as public-sector employees, kept them out of the middle-class mainstream, particularly as it took on a more developed ideological form in the 1920 s and $19305.5^{\circ}$

\section{PROFESSIONAL STATUS AND ITS LIMITS}

Discussion of these occupations as professions is characterized by two conflicting assumptions. The first is that insecure professions are established professions in the making - the notion, continuously advanced by their leaders, that if they can copy the characteristics of the established they will come to enjoy similar status and rewards. From the earliest days such issues as control of entry to the profession, self-regulation of training and discipline, and unification around common purposes and standards of conduct dominated internal debates. As early as i872, leaders of the National Union of Elementary Teachers were defining their purpose as the "service of society" and imagining a "brotherhood of teachers" stretching "from the headmaster of Eton to the humblest village teacher", which would give them the same dignity as other professions. ${ }^{\text {II }}$ The second assumption, best expressed in Etzioni's controversial study, acknowledges the permanence of the division between what he called the "semiprofessions", and the established, but assumes too readily that this rests on some obvious and enduring difference in professional capacity. ${ }^{2}$ The long history of thwarted aspiration does indeed suggest that relative insecurity was (and is) no temporary state, but it is wrong to assume that

48. Roxburgh, The School Board of Glasgow, p. I55.

49. See Philip Mairet, A.R. Orage: A Memoir (London, 1936).

50. McKibbin, Ideologies of Class, p. 275 .

5. Thompson, Professional Solidarity among the Teachers of England, p. 78.

52. A. Etzioni, The Semi-Professions and their Organization: Teachers, Nurses, Social Workers

(New York, 1969). Among many attempts to differentiate groups of professions we have "complete" versus "incomplete" (N.K. Denzin, "Pharmacy - Incomplete Professionalization", Social Forces, 1968), and "scientific" and "normative"; T.C. Halliday, Beyond Monopoly: Lawyers, State Crises and Professional Empowerment (Chicago, IL, I987), p. 32. 
the eminence of the established rested on a natural and unchanging superiority in the work performed.

In his most recent study Freidson has identified five defining elements of an ideal type of profession: (I) it will possess, "[a] body of knowledge and skill which is officially recognized as one based on abstract concepts and theories and requiring the exercise of considerable discretion". (2) There will be "an occupationally controlled division of labour"; (3) "an occupationally controlled labour market requiring training credentials for entry and career mobility"; and (4) "an occupationally controlled training programme which produces these credentials". (5) There must also be "an ideology serving some transcendent value and asserting greater devotion to doing good work than to economic reward". Developing Parson's distinction that "professional men are neither 'capitalists' nor 'workers' nor typically government administrators or bureaucrats", 53 Freidson suggests professions should be viewed as the third way, between the market and bureaucratic order, of organizing work: "I use the word 'professionalism"”, he writes, "to refer to the institutional circumstances in which members of the occupation rather than consumers or managers control the work they do". 54

It is not difficult to find historical support for Freidson's criteria. The National Union of Elementary Teachers, founded in 1870 , outlined its aims thus: first came "control of entrance to the profession" and teachers" registration; second, recruitment of teachers to the inspectorate; 55 third, the right to appeal against inspectors' decisions; fourth, superannuation rights; fifth, revision of the educational code; sixth, security of tenure; seventh, freedom from compulsory "extraneous duties"; eighth, adequate salaries; and finally "freedom from obnoxious interference". 56 The only element lacking is the "body of knowledge or skill" but this was always assumed and was very much in evidence in the activities of another representative organization of teachers. ${ }^{57}$ This agenda is remarkable in that it bore so little resemblance to the reality of teachers' lives. It was developed at a time when even that basic requirement of any profession, the identification of an area of work that members are uniquely qualified to perform, was fiercely contested.

53. Talcott Parsons, "Professions", International Encyclopaedia of the Social Sciences, (New York 1968), p. 539.

54. Eliot Freidson, Professionalism: The Third Logic (Cambridge, 2001), p. I 2.

55. Tropp argued that "of all the teachers' grievances $[. .$.$] it was the lack of promotion to the$ Inspectorate that was felt more keenly by the leaders of the profession and roused the deepest emotions"; Asher Tropp, The School Teachers: The Growth of the Teaching Profession in England and Wales from I 800 to the Present Day (London, I959), p. I I 8.

56. Ibid., p. II 3 .

57. See P.H.J.H. Gosden, The Evolution of a Profession: A Study of the Contribution of Teachers' Associations to the Development of School Teaching as a Professional Occupation (Oxford, 1972), pp. 194-234. 
All such professions seem to have faced this difficulty. We can cite the School Attendance Officers' Association in I 890, with a membership of only 429, desperately justifying its existence. Their Chairman pointed out that in the past, school board members had argued "that any man could be a School attendance Officer". However, by collective action, he claimed, they had "raised themselves in the social status, and had shown such Board members that they had some superiority in them, and that 'any man' was not fitted for the position of School Attendance Officer". Wages doubled once this point was established..$^{8}$ This remained an area of vulnerability for larger professions such as nurses and teachers, for their activities were often denigrated as tasks that could be performed by almost anyone. This led the British Nurses' Association, for whom professional status was the ideal, to campaign for high barriers for entry. As Abel Smith commented, "the very fact that every woman thought she could nurse made it the more necessary to emphasize and exaggerate training requirements". 59

School boards in the late nineteenth century took an aggressive line on professional ambition. When, in Spalding, an attendance officer complained that he was only paid $£_{3} 0$ a year, "Mr. Hall moved a proposition that if Mr. Proctor were not satisfied he should resign. They could get the work done quite as efficiently for 251 .[pounds] a year" ${ }^{60} \mathrm{Mr}$ Hall was no less hostile to teachers. In Glasgow the first school board was dominated by the upper middle classes with a paternalistic outlook, and supportive of professional aspiration. However, at subsequent elections such influence was restricted by the success of "rate-payer" candidates with narrower concerns and little sympathy for teachers.

When the state's interest in education was being extended in England in the mid-nineteenth century, under the influence of patrician enthusiasts like Sir James Kaye Shuttleworth, the teachers had been handled with sensitivity. This did not survive the Newcastle Commission of I858I 86r ${ }^{6 \mathrm{r}}$ Ignoring the favourable reports of its own investigators, it condemned teachers as "over-educated" and warned that they were producing over-educated pupils. ${ }^{62}$ Teachers, they claimed, were prone to "the use of ambitious language, vain display of knowledge", and errors, "into which an uneducated person falls". They were social upstarts: "[b]oys who would otherwise go out to work at mechanical trades at twelve or thirteen years of age, are carefully educated at the public expense", and are able to earn "about $£_{100}$ a year, by five days work in the week, the day lasting only seven and a half hours, and they usually have six or seven weeks' vacation". The Commission demanded rigorous inspection, but no

\footnotetext{
58. School Board Chronicle, I53 (I2 April i 890), p. 278.

59. Abel Smith, A History of the Nursing Profession, p. 62.

60. School Board Chronicle, I53 (5 April i 890), p. 245.

6I. British Parliamentary Papers, I86I, XXI.

62. Tropp, The School Teachers, p. 66.
} 
teacher could become an inspector: "[i]t is absolutely necessary that the inspectors should be fitted, by previous training and social position, to communicate and associate upon terms of equality with the managers of schools and the clergy of different denominations". ${ }^{63}$

This was a block on professional development and much resented by teachers: "The humblest lawyer's clerk [...] may sit on the woolsack one day $[. .$.$] the hard working curate on fifty pounds a year and furnished$ apartments may reap his earthly reward by becoming Archbishop of Canterbury or York", but the limit of the teacher's aspiration was the headship of an elementary school. ${ }^{64}$ In the Code of 186 I the curriculum was narrowed and payment by results based on examination passes and pupil attendances introduced. Pensions were withdrawn, as were rewards for attaining a certificate of qualification. Thus, albeit negatively, the politicians demonstrated a precise understanding of professional status. The minister compounded the insult by warning that without such measures the grant could become, "instead of a grant for education, a grant to maintain the so called vested interest of those engaged in education". ${ }^{65}$ Professional status is especially vulnerable to accusations of self-seeking and such criticisms have always dogged the insecure professions. Few subsequent commentators have matched the contempt expressed by the Newcastle Commission, although Lewis and Maude approached it in I952:

Girls who take the two-year training college are usually by no means the brightest of those who stay the extra year at school. Having secured a qualification at small expense, they find themselves at 20 with a permanent and pensionable job, three months holiday in the year, and a position which to many of them represents a clear advance in social status. Further, the job can be made an excellent training for marriage or a means of satisfying the maternal feelings of those who are less fortunate. ${ }^{66}$

Tropp suggested that class hostility was fuelled by success, for "uneducated persons" inconveniently demonstrated that they could produce more competent pupils than middle-class private schools. ${ }^{67}$ The more entry and progress became subject to formal examination the more it seemed to favour working-class candidates. It was recognized in the late nineteenth century that bureaucratically regulated competition made it difficult for middle-class girls to enter the teaching profession. ${ }^{68}$ The success of the elementary school teachers challenged the process of

63. Newcastle Commission quoted in Tropp, The School Teachers, p. 68.

64. Thompson, Professional Solidarity among the Teachers of England, p. 59.

65. Robert Lowe, quoted in Tropp, The School Teachers, p. 87.

66. Roy Lewis and Angus Maude, Professional People (London, 1952), p. 204.

67. Schools Inquiry Commission, Parliamentary Papers, I867-1868, XXVIII, vol. I, p. 546.

68. See for example, Holcombe, Victorian Ladies at Work; Jane Lewis, Women in England: Sexual Divisions and Social Change (Brighton, 1984); Widdowson, Going up into the Next Class. 
middle-class social reproduction and hence sharpened prejudice against the profession. The status of insecure professionals has always been compromised by the fact that they deal with a far broader client base than established professions. This has meant, as in the case of the teachers, that judgements of success are complicated by disagreement as to what their clients are entitled to expect. In the view of the Newcastle Commission success would be a matter of giving that minimum of education which would enable their working-class pupils to perform functions appropriate to their social station and no more.

The relationship between an established professional and a client is typically characterized as a personal one, with the interest of the client as its core objective. In contrast, the encounter between insecure professional and client is rarely initiated by the client and there is ambiguity as to whom the professional is serving. This was well expressed in a study of British social workers in the I940s:

To some extent, and in referral centres such as the old Charity Organisation Societies and the new Citizen's Advice Bureaux, the social worker has put out a brass plate and waited for clients to consult her about their individual troubles. To a great extent however the social worker has been envisaged as an agent of society, endeavouring to make society's many processes - judicial, educational, medical and industrial - more effective. ${ }^{69}$

In his study of social workers in the United States in the later part of the twentieth century, Daniel Walkowitz identified a hierarchy. ${ }^{70}$ At the bottom was the routine administration of state benefits undertaken by social workers, largely black, female, not well educated, with little professional training, and operating to a bureaucratically designed template. At the pinnacle was private social work, with encounters instigated by the client and conducted on a one-to-one basis. This was conducted by predominantly male, white, well-educated, fully trained social workers, and involved a high degree of discretion. Insecure professionals, here as elsewhere aspiring to the standards of the established professions, have usually acknowledged such a hierarchy with the personal encounter as the pinnacle even when it did not bear much relationship to their daily work. ${ }^{71}$

Similarly prestige diminishes in proportion the degree to which the professional is seen to be serving the state's purposes rather than those of

69. Hardy and Margaret Wickwar, The Social Services (London, I949), p. 282.

70. Daniel J. Walkowitz, Working with Class: Social Workers and the Politics of Middle Class Identity (Chapel Hill, NC, I999).

7I. The policy of the "named nurse", the allocation of a particular nurse to each patient, is a good example of an insecure profession attempting to personalize its relationships with clients. Under pressure from the Royal College of Nursing it was introduced into British hospitals in the r 990 . It appears to have had little practical impact. 
the client. However, no profession can operate without the state. A study of I 857 explained the prestige of lawyers and doctors on this basis: "They are more or less connected with the state; their importance is recognized by law."72 Escott, in 1880 , argued the standing of professions rested on "their stability, their remunerativeness, their influence and their recognition by the state". ${ }^{73}$ As Wilding put it much later, "What produces the privileges of professional status is a professional-state alliance." 74 What is at issue is not the connection between state and profession as such, but its nature. Prestigious professions depend on the state to establish and maintain their jurisdictions but they achieve this without compromising their status or operational autonomy.

British doctors provide an excellent example. The virtual nationalization of health care in 1948 provoked fears that the additional state involvement would compromise professional status, but the adoption of the doctrine of "clinical autonomy", under which it was deemed incompatible with professional dignity to subject a doctor to a manager or the direct control of a politician, and the preservation of the right to work privately, provided a sounder foundation of professional prestige than anything previously seen. ${ }^{75}$ Moreover, the bargain struck between the doctors and the state sealed the pre-eminence of doctors over all other health workers. ${ }^{76}$ The fact that services were "free at the point of delivery" exempted doctors from the necessity of extracting money from individual patients which had always posed a threat to claims of altruistic service. In reality, for the doctors, the NHS proved to be a model path between state control and the market, both of which can represent a challenge to professional status.

Insecure professions in Britain have always maintained an enthusiastic attitude towards state involvement even though none have achieved this kind of relationship. At one level they looked to the state as the best guarantor of basics. In I895 the Association of Poor Law Officers of Scotland announced themselves as "a warlike combination" bent on advancing "the aspirations of a worthy and long suffering class", but their immediate aim was to secure from the state what their English equivalents

72. Bryerly Thompson, quoted in W.J. Reader, Professional Men: The Rise of the Professional Classes in Nineteenth Century England (London, I966), p. I49.

73. T.H.S. Escott in England: Its People, Polity and Pursuits (London, I885), quoted in Reader, Professional Men, pp. I I-I 2 .

74. P. Wilding, Professional Power and Social Welfare (London, I982), p. I 2.

75. W.J.M. McKenzie, Power and Responsibility in Health Care: The National Health Service as a Political Institution (Oxford, I979).

76. The consequences became apparent in the Cope Committee when doctors secured effective control of the bodies which regulated all other health professions, except nurses and almoners; The Report of the Committees on Medical Auxiliaries, House of Commons, cmd 8188 (April I95I). 
had achieved in the Superannuation Acts of 1864 and I 865.77 Teachers similarly looked to the state as the only effective means of securing adequate pensions. ${ }^{78}$

At a second level, state involvement was welcomed on the grounds that a national master was better than a local one. In the r 880 s English teachers' leaders argued that professional dignity would return when questions of pay, curriculum, and inspection were again lodged in a remote body. Subjection to local school boards had reduced the teacher's status: "[f]rom being a servant of the state he had become a servant of the manager". ${ }^{79}$ In I 898 the Scottish Poor Law Medical Officers' Association argued the power of local guardians to dismiss them should be removed and lodged in the Local Government Board for Scotland. "Your petitioners", they argued before the Scottish Secretary,

[...] would also draw your Lordship's attention to the fact that it is against the best interests of the sick poor that the medical officer should have such an insecure tenure of office, because he may have to consider what is pleasing to the Parish Council rather than what is best for the sick poor under his charge. ${ }^{80}$

Judgements of the interests of the client should ideally be in the hands of the professional, but failing this, the more Olympian the supervision the better. Similarly the Educational Institute of Scotland campaigned for a state-determined salary scale on the grounds that it would remove "the anomaly whereby a branch of the public service is made to depend for tenure of office and emoluments on the capricious action of local boards". ${ }^{8}$

In the third place the state, or rather a future state, was seen as the only means of achieving higher aspirations and securing some influence over the broader field of education. In this context, the appeal of the Webbs' contribution can be understood - the notion that the state indeed was to be in charge but that the "expert specialization" inherent in teachers' organizations equipped and entitled them to exert a strong influence on how the state should interpret its responsibilities. ${ }^{82}$ Their support was not

77. “A Call to Arms", Poor Law Magazine and Local Government Journal, ns, 6 (February, I 896).

78. Poor Law Magazine and Local Government Journal, ns, I (October I89I), p. 3 I 5.

79. Tropp, The School Teachers, p. 96.

80. Poor Law Magazine and Local Government Journal, ns, VIII (March, I898), p. Io8. The Association also used another argument widely deployed by public-sector workers in Scotland that they deserved the same treatment as their equivalents in England.

81. Poor Law Magazine and Local Government Journal, ns, I (October I 891), p. 309.

82. "The conditions of employment depending on the degree of expert specialisation to which the craft has been carried, and upon public opinion as to its needs, each Trade Union will find itself, like the National Union of Teachers, more and more concerned with raising the standard of competency in its occupation, improving the professional equipment of its members, "educating their masters" as to the best way of carrying on the craft, and endeavouring by every means to increase its status in public estimation"; Sidney and Beatrice Webb, Industrial Democracy (London, I902), p. 826. 
unqualified; professions involved "a certain identity of pecuniary interest against other classes". Any "powers of government" delegated to a profession in the socialist commonwealth would still be circumscribed..$^{83}$ Nonetheless, the Fabian approach was close to insecure professional aspiration. A socially active state would be the means of releasing the professions' potential for positive intervention. Poor law officers were not alone in expressing frustration that they were only allowed to act when an individual had slipped into destitution: "We begin to look after him when it is too late". 84

Such frustration produced admiration for countries with a more active social state. Thus, we find a Scottish poor law officer advocating a more "vigorous" policy towards the destitute: "The Germans teach us a lesson here as they do in so many other matters and which this country would do well to copy and put into practice." 85 In arguing that midwifery in England could only be improved by instruction, licensing, and supervision, an author in 1872 praised "Prussia" where such matters were better organized. ${ }^{86}$ That a different relationship between state and society elsewhere produced a more comfortable status for the social professions was a recurring theme. This led many to consider socialism as a model for the future, but the socialism advocated contained no element of class antagonism, and was akin to that "socialism for non-socialists" 87 which the radical Speaker yearned for. Social experts would sort out the problems of modern life free from the interference of miserly school managers, reactionary guardians, and opportunistic politicians. As the Rev. Thomas Hannan, M.A. put it, "In a very high and noble sense every thinking man who desires and strives to help on the progress of humanity is a socialist." 88

\section{STATES, REAL AND IMAGINED}

Insecure professions have always sought to improve their condition by trying to emulate the established. The British Nurses' Association believed that the only way for nurses to acquire the prestige of the medical profession was through imposing high barriers to entry to encourage a better class of entrant. They campaigned, quixotically, against payment during training and opposed the registration of existing nurses on the basis of experience

83. Report of the Fabian Research Department, "The Control of Industry", part of which was published as a New Statesman Special Supplement, 28 April 1917, p. 45.

84. "The Rich and the Poor and their Relations with Each Other", Poor Law Magazine and Local Government Journal, ns, 9 (October i 899), pp. 308-3 I0.

85. "Some Experiences of a Parish Medical Officer", Poor Law Magazine and Local Government Journal, ns, 7 (October I897), p. 3 is.

86. J.H. Aveling, English Midwives: Their History and Prospects (London, I872).

87. Editorial, The Speaker, iо May i 890.

88. Poor Law Magazine and Local Government Journal, ns, 9 (October I 899), p. 3 I 2. 
alone. Most insecure professions have from time to time attempted to instigate registration on the lines of the General Medical Council, but when English teachers attempted this in the 1890 s the result was "an almost comical travesty of a Professional Council". ${ }^{89}$ Teachers could not agree whether elementary and secondary teachers were part of the same profession and ministers and officials created a Council devoid of teachers' representatives..$^{\circ}$ Nurses' councils have fared better. The Royal College of Nursing, with powers over education and registration, was formed in I9I 6 and the General Nursing Council followed in 1920, but neither achieved the authority or control of doctors' and lawyers' organizations.

So while such factors as the social characteristics of entrants, degree of self regulation, operational autonomy, and the like do suggest a division among professions, and while they have set the terms of the battles of the insecure, they never provided a route map to established status. It is useful to draw an analogy with wealth. There are a number of external attributes associated with the wealthy. Aspirants might assume some of the external characteristics but this would not make them wealthy. At root, wealth involves control of a disproportionate share of the world's material resources. And so it is with professions. While the outward display of professional attributes constitutes the public appearance of professional power and is of great importance in legitimating, projecting, and sustaining that power, it does not produce it. Sustained authority rests on power.

Professional status rests upon the ability to exercise a disproportionate share of power within a restricted area. It is produced and maintained by a leadership with a capacity to act politically and a membership that recognizes its interests are best served by the maintenance of unity. The key currency is skill and, as Polyani recognized, skill is a characteristically modern form of property, and as Weber saw, the ability to secure rewards in modern societies can rest on either property or skills or both..$^{9 \mathrm{I}}$ But skill alone is not enough. Thus Larson defines professionalization as "an attempt to translate one order of scarce resources - special knowledge and skills - into another - social and economic rewards", or "the process by which producers of special services sought to constitute and control a market for their expertise"..$^{2}$ So, just as the acquisition and retention of older forms of property rested, in the last analysis, on politics, so too with "skill property".

Abbott advances a similar argument. ${ }^{33}$ Successful professions, he argues,

89. New Statesman Special Supplement, 28 April I917, p. 44.

90. Gosden, The Evolution of a Profession, pp. 239-250.

91. Karl Polanyi, The Great Transformation (Boston, MA, 1957).

92. M.S. Larson, The Rise of Professionalism: A Sociological Analysis (Los Angeles, CA [etc.], 1977), pp. xvi-xvii.

93. Andrew Abbott, The System of Professions (Chicago, IL, I988). Abbott usefully divides students of professions into two categories; functionalists and monopolists, pp. 5-6. 
have to be understood not on the basis of their social esteem, but on the basis of their ability to establish and monopolize a jurisdiction. They identify an area of work, they banish competitors, and they project themselves as uniquely ordained to undertake it. Then, in negotiation with the state, a jurisdiction is defined and a corporate relationship established: the profession delivers the necessary service within their area and the state protects that area. Thus professional power, the property of the profession, rests on nothing more an ability to control and execute work within protected boundaries.

Abbott suggests that the more familiar ways we have of defining professions: social esteem, privileged relationships with clients, effective control of entry to the profession, the possession of a discrete body of expert knowledge, even the capacity for unified action, should be seen as the consequences of successful profession-building rather than the causes. This has implications for how we study professions. We should recognize the familiar studies of the "rise" of individual professions as promotional legends and focus on the political struggle for jurisdiction. Having carved out a jurisdiction, a profession must continue to defend it from, for instance, external competitors, who may be defeated or incorporated, and visibly incompetent members. The defence of a jurisdiction is not simply a matter of hanging on to every function. It will, for example, demand a periodical review of the portfolio, protecting what is vital but discarding what has become so routine as to bring professional status into question. An established profession will promote its right to pre-eminence, but its capacity to defend its jurisdiction will be more critical for its survival. The position of lawyers, after all, does not rest on public popularity but on dominion over a jurisdiction which other groups and individuals will need to enter periodically.

This suggests a clear difference between established and insecure professions. The latter simply have no secure working jurisdiction, no zone of exclusive responsibility. Some work under bureaucratic control, some operate in confused jurisdictions, while others must pursue their occupations in an area where the supremacy of another profession is firmly established. From this deficiency flow the difficulties in establishing unity, developing effective leadership, and strategically managing the portfolio of functions. Professions with secure jurisdictions will exhibit a political style which is, in most circumstances, defensive and precise, whereas the politics of insecure professions will tend, of necessity, to be promotional and diffuse. Typically, the latter will have one section for whom progress demands a stricter adherence to professional criteria and another which advocates the adoption of trade-union tactics; a perfect representation of the ambiguities inherent in the insecure professional status.

However, while the distinction is clear, it does not mean that the concept of professionalism becomes irrelevant, for if the insecure cannot 
become established, neither can they be reduced to mere employees. Earlier aspirations to reduce the work of such professionals to carrying out functions according to predetermined rules were never realistic. No matter how much effort was put into reducing the duties of nurses, teachers, or social workers to formulae, there remained in their dealings with clients an inescapable element of discretion requiring a degree of autonomy. Politicians have usually been compelled to recognize that rigid control would reduce the morale of the profession to the point where it could longer function efficiently. Some have also seen that a concession of limited autonomy is also prudent because insecure professionals work in contentious areas and some of their decisions and actions will always result in visible failure or even public scandal. A measure of professional autonomy ensures that all the responsibility does not immediately settle on the shoulders of the politician.

However, situations will always occur, arising perhaps from a desire to reduce costs, a need to drive policy in a new direction, or because professions are operating in ways which are producing political difficulties, when politicians will feel the need to assert control. Thus the autonomy of an insecure profession is both limited and subject to periodic adjustment. As Lewis and Maude argued in 1952 the "state has a firm grip on these two professions [nursing and teaching]" ${ }^{94}$ The result was a "nice balance of poor salaries, poor conditions of work and second rate qualifications" which enabled services to get by. "State subsidised dilution" produced a professional status which, though a deterrent to some, was just "high enough to make it appear a step up the ladder to adequate numbers of young men and women in the lower middle class". ${ }^{95}$ While insecure professions have always aspired to do more than carry out predetermined functions and have asserted their right to express a broader view on their work, they have here, as elsewhere, failed to match the success of the established.

From the first, when insecure professions sought to articulate their condition and demand improvement they used broad, idealistic arguments. A correspondent of the British Medical Journal noted that "lady nurses", "if very much in earnest tend to be dominated by some principle or power". ${ }^{6}$ A retiring president of the NUT, searching for what was really lacking in the profession, produced a plea for "culture". ${ }^{77}$ Teachers had opposed

94. Lewis and Maude, Professional People, pp. 155-156.

95. Ibid., p. 197.

96. British Medical Journal, i7 March I880, quoted in Abel Smith, A History of the Nursing Profession, p. 27.

97. "The organized thousands of the National Union of Teachers have aspirations towards that high intellectual plane which has come to be embodied in one word - 'culture"'; James Blacker, Presidential address to the National Union of Teachers conference, quoted in Tropp, The School Teachers, p.I7I. 
payment by results because they encouraged "a low mercenary spirit" 98 totally at odds with their "earnest desire to make the next generation more intelligent, more moral and more religious than the present". 99

The disposition to ideological complaint was formed less by simple despair than by enthusiasm meeting limitations. The theoretical potential of such professions stood in marked contrast to the political space within which they operated. Their very existence challenged notions of social hierarchy, particularly those associated with class and gender, as did the fact that they operated on the moving ideological frontiers of British society, where debates about how to deal with social casualties and the respective rights of the individual and society were fought out. As Escott noted, the I 870 Education Act involved the application of "Prussian" ideas to "free and independent England": "No such organised intervention between parent and child, no such systematic inquisition into those private affairs which Englishmen are in the habit of keeping religiously to themselves had ever been attempted in this country." 100 Teachers were in the political front line without the protection of a secure jurisdiction. Where established professions could deal with politics in a conservative, limited way, and exploit advantages already won, the insecure were, by necessity driven into wider promotional mode. Moreover, a sense of momentum towards a better future helped distract attention from their organizational disunities and internal disagreements.

For such professionals, the debate over the state stirred up personal issues as well as ideological ones. When teachers' leaders spoke passionately about education it could simply be a plea for better schools and better-paid teachers. However, it could also involve a celebration of education as levelling politics, social advance by competitive examination as celebrated in H.G. Wells's social novels, or even that progressive notion of education as the cure-all: the belief that an educated population would be immune to jingoistic politicians and the "yellow press" and receptive to higher ideals. Similar depths of meaning became attached to such notions as caring: at one level a necessary function, at another, a heightened moral awareness of the needs of others, with a hint of moral superiority over those driven by more sordid considerations. It could even be a principle around which a whole society might be transformed, and disinterested work in education, health, and social care allowed to achieve its potential. Thus, district nurses saw themselves as responding to the immediate needs of patients but also as "health missioners" to the people as a whole, with a duty to spread the gospel of cleanliness and neatness and produce a happier society. ${ }^{\text {II }}$

98. Thompson, Professional Solidarity among the Teachers of England, pp. 67-68.

99. Ibid., p. 78.

ı०o. Escott, England: Its People, Polity and Pursuits, p. 83.

IоI. Holcombe, Victorian Ladies at Work, pp. 89-90. 
Progressive remedies ranged from the universal to the minutely particular. The Scottish Health Reformer, complained on the one hand, "The nations seems to be governed in the interests of commerce rather than the well being of the people", ${ }^{102}$ while on the other warned that only air and light baths "in a state of perfect nudity" would produce healthy individuals and societies. ${ }^{103}$ Diet and dress were no mere details. What it all amounted to was a new kind of political engagement, a development of public discourse to accommodate those who could scarcely aspire to actual leadership but did not see themselves as the raw material of the historical process. The new politics was earnest and disinterested, its vision elevated and permanently focused on the better future. It was not confined within traditional political forms. Purposeful research, voluntary social work, discussions with the like-minded, applying ethical criteria to daily decisions and, perhaps above all, doing one's job in an appropriate frame of mind, could all be seen as fields of political action.

Such an outlook was ideally suited to the needs of more active representatives of this newly emerging stratum. As a group they were searching for a plausible account of their place in the world, and this drove them to establish themselves as a wedge of ethical dissent in the broader society. The social philosophy was about changing society, but it could also help individuals find a place within it. For those who felt they had stepped beyond the consciousness of ordinary men and women but had no hope of glittering prizes, it offered a version of the world in which their skills were valued and their occupations ennobled. It was a particular mental living space, amounting in its most perfected form to a state of internal exile in the midst of commercial society. It was a world where a humble professional might enjoy a quiet insight into a new social order beyond the imagination of the most powerful politician.

This emerging audience with its special needs helps explain the rise of the progressive intellectual milieu: the magazines, the societies and the new intellectuals; and, for instance, the appeal of Shaw's counterintuitive world where servants were more capable than their masters, women stronger than their husbands, and "respectable" citizens infinitely more immoral than those of whom they disapproved. It helps explain the popularity of Wells's tales of ambition forced through the grind of competitive examinations, and indeed the Fabian promise of a state and economy stripped of competitive uncertainty.

As I have argued elsewhere, the work of Havelock Ellis was attuned to the needs and interests of this community. He produced in the Nationalisation of Health a plan for state-funded health experts to create the hygienic society. In The Criminal he produced a plea for a socio- 
psychological-curative approach to criminal justice to replace a moral and punitive one. The social expert would displace judge, jury, jailer, and hangman. In his works on sexuality he offered guidance appropriate for modern people escaping traditional restrictions. His espousal of eugenics was a logical, if to modern eyes unfortunate, assertion of progressive common sense, rooted in the proposition that human sexuality could be recreated as an inconsequential pastime and reproduction transformed from an involuntary cycle into a premeditated choice, under the guidance of experts. Motherhood was also reconstructed into a subject to be taught by a new kind of expert. This replacement of quantity with quality in reproduction was a generalized ideal, but could also be understood as good practical advice for those struggling to maintain a middle-class life style on a limited income.

A shelf of progressive texts, a magazine subscription or attendance at a meeting was a sign of emancipation, a demonstration that even if one was not able to follow one's highest inclinations, one was at least in touch with those who could. Edwin Muir recollected that his subscription to the New Age "gave me a feeling of superiority". ${ }^{104}$ This politics was, emphatically, something that could be learned from a book; abstraction was everything, experience nothing. The new intellectuals were champions of the new men and women and their new society was designed to provide the perfect outlet for their talents.

Communities of sentiment are created as much by opponents as supporters. T.W.H. Crosland wrote of a hell of mediocrity called "suburbia" which he associated with the "morbid movements" of progressivism; Wells had made it "idiotically sure of itself" and Shaw had spoken directly into its "wretched soul". ${ }^{\text {Ios }}$ Crosland can be seen as an early participant in a discourse of the deaf which was to run through twentieth-century Britain; on one side, a celebration of the disinterested virtues and expertise of the insecure professionals; on the other, a vituperative dismissal of them as a bossy, half-educated, humourless, and, later in the century, "Guardian-reading" crew, bent on increasing their own power and interfering with the pleasures of others. ${ }^{106}$

Two key elements are missing from Crosland's analysis, and similar ones that followed. Firstly, a recognition that the insecure professions were not "outdoor relief" for the middle orders. They developed as a means of dealing with a set of needs that arose in the course of social development. These needs were bluntly defined in an account from the middle of the twentieth century which saw the social worker as: "an agent

104. Muir, Autobiography, p. I23.

I05. T.W.H. Crosland, Suburbans (London, 1905), p. 202.

I06. For a good recent example on the pro side see Richard Sennett, "We May Not Be Rich but We Are Useful”, The Guardian, 20 March 200I. 
of society, endeavouring to make society's many processes - judicial, educational, medical and industrial - more effective. To win people's consent, enlist their co-operation, and help create conditions favourable to that passive consent and this active co-operation." I07 Secondly, an appreciation that the basic work of insecure professionals often involves responsibility for society's more uncomfortable transactions. This comes across clearly in a practitioner's recollection of social work in Glasgow in the I970s:

There was a different kind of loss that people were dealing with. Loss of, loss of innocence, loss of childhood, you know, people who had to grow up quickly. Loss of dreams [...] you know, of a nice marriage; loss of the ability to get out of the housing estate. ${ }^{\text {I08 }}$

Such professionals operated at the point where state and society met the individual. They were messengers of obligation, witnesses to misfortune, and, so often, administrators of society's zero sums. They rarely had much influence over the creation of the rules they applied although they could bend them. Any heroism they displayed was of a quiet variety. Their broader impact was rarely clear-cut but it would be a mistake to underestimate it. The distinct character which many members of the "caring" branches of the public service in Britain have exhibited: that sense of purpose in excess of the job description, of vocation above the vulgar criteria of commercial society, has, while conferring a measure of dignity on difficult callings, propagated the notion of an inevitable separation of "caring and serving" from the world of "getting and spending". This established a potent and enduring division in the British middle class and in British politics in general.

\section{“INSECURE PROFESSION" AS A BASIS FOR COMPARISON}

I have developed the argument to this point largely in terms of British experience, but the notion of the insecure professional, if it is tenable in the terms I have outlined, should be more broadly applicable. The leaders of the British insecure professions were always conscious of being part of some larger process of social change and paid close attention to developments elsewhere. ${ }^{109}$

Even a superficial look at developments in the USA produces many parallels. Lubove argued that the American social-work profession rose on a wave of concern to "avert the worst consequences of an urban industrial society: pauperism, social atomisation, class hostility and the destruction

107. Wickwar and Wickwar, The Social Services, p. 282.

ı08. Glasgow Caledonian University Archive, Special Collections, Almoners, GCU/CCH Ti o.

109. Daniel T. Rodgers, Atlantic Crossings: Social Politics in a Progressive Age (Cambridge, MA, 1998). 
of the family". ${ }^{10}$ Similarly, Kirschner suggested that the origins of the range of caring professions can be found in the social reform movements which developed "when urban problems became too great to handle by

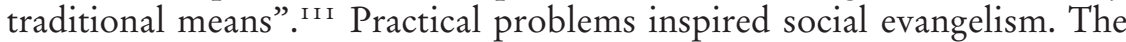
Boston Associated Charities aimed to save the urbanized individual from "the vast selfishness which, like a vapour is exhaled from these unnatural conditions $[\ldots]$ changing him from the warm-hearted provincial to the cautious citizen." II2 Jane Addams wrote of "that sentiment of brotherhood, which the best spirit of our times is forcing from an emotion into a motive", and recognized a blending of social and individual purposes in the activists. Workers were driven by a "fatal want of harmony between their theory and their lives": "How eagerly they long to give tangible expression to the democratic ideal [...] to socialize democracy". ${ }^{113}$ More directly, there was the desire to create a field "offering creative professional carer opportunities for women". ${ }^{I 4}$ As Trolander commented, "the settlement house offered" the worker "a solution to both her occupational and personal dilemmas"; not only a job and a means of leaving home but a purpose to protect her from accusations of selfishness. ${ }^{\text {II }}$

At the beginning, the social professions expressed their purposes in openly political terms. They sought to bring poverty to the attention of the broader society and explain to the respectable that deficiencies in their poorer neighbours arose from environmental rather than moral failings. ${ }^{116}$ The next stage involved a move towards professionalization, prompted by a desire "to demonstrate a greater claim to authority than class affiliation" and a need to equip themselves for the battles with established professions. Medical social workers, for example, faced physicians who were "hostile, lukewarm or indifferent". ${ }^{117}$ But Trolander was surely correct to argue that professionalization was not an abandonment of the broader commitments but a tactical response to changing circumstances. Kirschner noted that "expertise donned the armour of professionalism in the form of special journals, organisations and educational requirements", ${ }^{118}$ but agreed with Trolander that this was not an abandonment of higher purposes but a means of pursuing them more effectively and escaping the stigma of being

I I0. Roy Lubove, The Professional Altruist: The Emergence of Social Work as a Career I8801930 (Cambridge, MA, I965), p. I4.

I I I. Dan S. Kirschner, The Paradox of Professionalism: Reform and Public Service in Urban America 1900-1940 (New York, I986), p. I.

I I2. Lubove, The Professional Altruist, p. is.

I 13. Jane Addams, Twenty Years at Hull House (New York, I949), p. I 16.

I I 4. Lubove, The Professional Altruist, p. 3 I.

I I s. Judith Ann Trolander, Professionalism and Social Change: From the Settlement House Movement to Neighborhood Centres, I 886 to the Present (New York, 1987).

I I6. Ibid., p. 5 .

I 17. Lubove, The Professional Altruist, p. 24.

I 18. Kirschner, Paradox of Professionalism, p.6. 
an ineffective "do-gooder". ${ }^{19}$ Professionalization did not lead to greater occupational fragmentation. Leaders "preached a gospel of cooperation across the boundaries of expertise". There was "a spirit at work" and agreement over "how they perceived and evaluated various forces in the modern world". ${ }^{20}$ Unity was reinforced by opposition to vested interests. Public health workers, for example, saw the American Medical Association as enmired in self-interest, while they disinterestedly pursued the goal of public health improvement. ${ }^{\text {I2I }}$ For Kirschner, "the common concerns of the reformers drew them together into a vaguely defined demi-class in American society". ${ }^{122}$

Somewhat to the surprise of the social professionals, opposition was not confined to vested interests. The "need to shield an educated elite from political sniping" became "a recurrent theme among professionals", but as with their British counterparts, this proved difficult. Although professionals in social welfare, public health, and city planning saw themselves as experts in the "disorder of urban life" and "handmaidens of modernization", ${ }^{123}$ they never achieved the protection which full professional

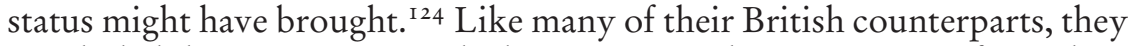
concluded that instruction and education were the means to reinforce their position. ${ }^{125}$ Failure did not diminish ambition. The search for professional status, a greater capacity to define and control the situations in which they worked to enable them to advance the interests of their clients, remained a clear, if elusive ambition.

One final example will also suggest that the issues raised go beyond the confines of a particular time and place. In a study of individuals caught on the margins of society in the I990s, Pierre Bourdieu interviewed a number of French teachers and social workers. They revealed a very particular type of "social suffering", arising less from material conditions than the gulf between the reality of their occupations and their professional aspirations. Professional idealism and altruism had become a source of acute personal discomfort. They had a clear and accurate notion of their clients' needs but little capacity to meet them. Their ability to provide even the minimum service compatible with their sense of professional duty was undermined by successive external impositions.

For example, political decisions, prompted by non-educational criteria, decreed that many students should stay in school far longer than their

I 19. Ibid., p. 55 .

I20. Ibid., p. I I.

I2 I. Ibid., p. 63.

122. Ibid., p. x.

123. Ibid., p. xi.

I 24. A key factor for Flexner in the rendering social workers of a lower professional status than doctors was the fact that they (and other similar professionals) relied on cooperation with others to achieve results; ibid., p. 53-54.

I 25 . Ibid., pp. 64-65. 
abilities, inclinations, or chances of success justified. Teachers' attachment to education as a value made it impossible for them to oppose such decrees, but other externally imposed decisions made it impossible for them to respond creatively. They were required to pass a high, pre-determined, percentage of students, their power to exclude the disruptive was severely restricted, and cost-cutting denied them the possibility of providing students with "intensive, individualized assistance", which was "indispensable given the growing number of students with minimal cultural capital who have more to learn at school." ${ }^{26}$ One teacher complained that the school was "becoming a place of non-education". ${ }^{127}$ As Bourdieu put it, "the absence of measures to counteract the effects of these demagogic and uncontrolled policies has thrown the teaching system into a profound crisis of which the demoralization of teachers is at once an effect and a component". ${ }^{128}$ Moreover, "the difficulties they meet are felt all the more acutely because the causes of these problems are so little understood that it makes it possible to saddle them with the responsibility and the blame". ${ }^{129}$ Teachers were trapped between students who viewed them with hostility; "You want to welcome them as friends and you become enemies", ${ }^{130}$ and managers with whom they were permitted no dialogue.

Interviews with social workers also revealed the insecure professional condition in crisis. Professional duty trapped them on "the antinomy between the logic of social work, which is not without a certain prophetic militancy or inspired benevolence, and that of bureaucracy, with its discipline and its prudence". ${ }^{13 \mathrm{I}}$ Their occupations put them into the front line of major social conflicts but their professional status, far from offering protection, only increased their vulnerability. Professional values, internalized as personal morality, meant they were committed to furthering their clients' interests, but severe limitations on their influence meant that they could do little. Insecure professional status meant an acceptance of responsibility for a situation over which they had no control.

Any proper cross-national comparison is beyond the scope of this article but the possibilities are interesting. Rueschemeyer suggests that one of the complexities in cross-national comparisons of legal professions are variations in state form which heavily influence the size, structures, and development of national professions. ${ }^{\mathrm{I} 2}$ It seems likely that state form

I26. Pierre Bourdieu et al., The Weight of the World: Social Suffering in Contemporary Society (Cambridge, 1999), p. 456.

I27. Ibid., p. 490.

I28. Ibid., p. 462.

I29. Ibid., p. 455 .

I30. Ibid., p. 488.

I3 I. Ibid., p. I90.

I32. Dietrich Rueschemeyer, "Comparing Legal Professions Cross-Nationally: From a Professions-Centred to a State-Centred Approach", American Bar Foundation Research Journal, (1986), pp. 4I 5-446. 
would prove an even more interesting basis of comparison in the case of insecure professions.

\section{SUMMARY AND CONCLUSION}

These insecurities of these professions meant their members had an intense, and often uneasy, experience of modernity in both the context and the content of their working lives. While they cannot be understood except in terms of professional aspiration, their experience is substantially different from that of the established professions and demands a different type of analysis, and there are sufficient elements of a common condition to justify dealing with social workers, health workers, and teachers as a common category. Dealing with them collectively reveals aspects of experience that would not emerge if they were dealt with singly. Insecurity in its several aspects does seem to be the most significant factor in the common condition and there is no reason to assume that it is not permanent. Because of these characteristics and because their professional duties often placed them on the front line of social change, the interreaction between the insecure professions and the rest of society has been more extensive and more interesting than that of established professionals. They have been the bedrock of a particular political outlook which has emphasized both the practical and moral importance of collective approaches to social, educational, and health questions and have, as such, made as distinctive a contribution to political culture as to civil society.

Formulating issues in this manner suggests ways in which studies of such professions can inform important bodies of historical argument. Elias's notion of the "civilizing mission", for example, suggests one link, for the burden of inculcating acceptable standards from the late nineteenth century onwards has fallen disproportionately on insecure professionals, from midwives supervising pregnancy and birth, health visitors ensuring that babies and young children were nurtured on acceptable lines, teachers managing the child's transition from private to public existence, and even, ever increasingly, nurses inculcating an etiquette of death into the departing and their relatives. Insecure professionals could also be seen as key functionaries in Polsky's "therapeutic state", and Lipsky's formulation of the "street-level bureaucrat" suggests a productive way of how their powers of passive resistance might be productively examined. ${ }^{133}$ Above all this formulation of the condition should suggest ways of escaping the unproductive dichotomies which have characterized many

I33. Andrew J. Polsky, The Rise of the Therapentic State (Princeton, NJ [etc.], I99I), Michael Lipsky, Street-Level Bureaucracy: The Dilemmas of the Individual in Public Services (New York, 1980). 
studies in the recent decades; on the one hand, the legends of such professions as bearers of enlightenment, on the other, the Foucaultinspired determination to see them as no more than "judges of normality" and agents of alien "social control".

I suggest that the order such professions set out to create can neither be accepted uncritically nor dismissed as inevitably at variance with the interests of the subjects involved. Any attempt to influence individuals' behaviour can be inappropriate or excessive, but it is surely only the most optimistic anarchists who are entitled to assume that all such activities are illegitimate. Others who advance such arguments must propose alternatives or explain why they are not necessary. All professionals, established and insecure alike, can act in tyrannical ways and we should acknowledge the elements of discretionary power in the decisions they take, but we should neither assume that their judgements of clients' interests can always be relied upon, nor assume that they never can. Professionals do not merely perform tasks as ordained by others but neither are they free agents. They are both judges and judged. We should, moreover, recognize that by the assumption of responsibility such professionals are denied the comforts of disengagement, for in their situation to take no decision is still a decision and no less attended with consequences. The practical result of blanket condemnation is, ironically, to hinder the discussion of the scrutiny and criticism to which these professionals, like all who exercise power over others, should be subject.

Finally, I must acknowledge the high level of generalization on which the argument rests. The experience of all insecure professions was not identical. One would not wish to deny, for example, the marked contrast in public esteem in which nurses and social workers have been held in Britain in the twentieth century. However, while this brought benefits to the former, they never succeeded in using their popularity to restructure their professional position. Agency should not be entirely discounted, but while some groups played their cards better than others, the original hands were not dissimilar and there were common limits to what even the most brilliantly played hand could achieve. Nor do I suggest that the formulations advanced here cover all the responses of individuals who worked in these professions. Many insecure professionals have had limited ambitions and been satisfied with their occupations. Others, without doubt, reacted to disappointments passively and simply got on with their work. Many held, and hold political views outside the broad framework I have advanced here. Yet such qualifications no more undermine the core proposition than the existence of conservatively inclined or apathetic working people invalidates the notion that the Labour movement was the vehicle for the expression of working-class aspiration through most of the twentieth century.

When the more active members in these professions sought to define a 
collective condition and come to terms with the public space in which they operated, they were drawn in these directions for, if they were mistrusted by their working-class clients and despised by the established middle classes, they were aristocrats in the kingdom of progressive ambition. Sir James Kaye Shuttleworth in his address to the National Union of Elementary Teachers in I 886 demonstrated an acute insight into this sensibility when he described teachers as "an army of light". ${ }^{134}$ The quiet virtues of this secular clerisy were not widely valued: the prizes still went to those with the means and confidence to throw themselves into the rough and tumble of public life, yet the progressive formulation affirmed that righteous activity on the periphery would triumph. This, of course, couldn't happen, but they endured, maintained a dignified account of their professional condition, retained an ability to challenge, if not change, the confines within which they worked, and to articulate, if not always advance, what they saw as the interests of their clients. In the end their influence proved greater than their early detractors could ever have imagined. 